\title{
DESCRIPTION OF THE PREPARATORY STAGES OF GPAPTA COMMA, HARRIS.
}

BY W. H. EDWARDS, COALBURGH, W. VA. .

EGG.-Conoidal, the base flattened and rounded; marked by 10 vertical ribs which near the base are low, but on upper third are considerably elevated, increase gradually in prominence and terminate abruptly around a small flat space at summit; these ribs are thin and their sides are cut by grooves perpendicular to the surface of the egg; the spaces between them crossed by many fine strix; color green. Duration of this stage $\mathbf{5}$ days in April, 4 in July.

Young Larva.--Length . 08 inch; cylindrical, even from 2 to 7 , then tapering slightly to extremity; on 2 is a dorsal chitinous patch on which are six tubercles, three on either side the medio-dorsal line, each with black hair; below the patch two tubercles, one above, the other below spiracle; on segments 3 to 13 are two dorsal rows of large tubercles, one to the segment, on the anterior part of same, each with long curved hair, from 3 to 7 turned forwards, the rest recurved; next, a row of small tubercles from 3 to 13 ; on 3 and 4 these stand in vertical line with the dorsals, but on the other segments they are back of the line of dorsals; a third row from 5 to 13 of small tubercles, in vertical line with the dorsals, and on 2 to 4 these are continued a little below the line of the other segments; on 3 and 4 is a short row, in line with the spiracles, and a corresponding tubercle appears in $\mathrm{r}_{3}$; and below spiracles, from 5 to $\mathrm{I}_{3}$, on the posterior part of each segment, is a minute tubercle; finally, along base of body is a row of minute tubercles from 2 to 13 , on 2, 3, 4 one to each segment, also on $\mathrm{I} 3$, but on the other segments two to each; from all these tubercles proceed hairs, those of basal row turned down, but of the others, from 2 to 7 turned forward, the rest recurved; color whitishgreen ; feet and legs green; head rounded, bilobed, the vertices rounded; color dark brown; many black hairs scattered over the surface, curving down. Duration of this stage 4 days in April, 2 days in July.

After Ist moult.--Length . I 3 inch ; color either brown-black, or black with whitish lines at the junctions of the segments; armed with seven rows of branching spines (disposed as described under mature larva); these spines are short, stout, black, and beset with short divergent bristles; in the examples which have white lines, on segments $4,6,8$, 10, the spines spring from whitish tubercles, on the other segments from black; 
in the black examples all tubercles are black; on 2 is a chitinous band with four small spines in cross row; besides the seven principal rows, there is a row of minute spines over legs and feet; feet black; legs olivaceous; head round, depressed at ton, the vertices a little produced, each bearing a short, thick process, with short spines at top ; color of head and processes dark brown; many black hairs over surface springing from fine tubercles. Duration of this stage 3 days in April, 2 in August.

After and Moult.-Length.3 to .33 inch; same shape; color dark olive-brown or black-brown or reddish-brown, individuals varying; the spines longer, and at one-third from the top give off branches; the posterior end of each segment after 2 crossed by two or three fine white iines; in front of the medio-dorsal row of spines are two oblique divergent whitish bars, one such bar from base of each spine in rst lateral row on outer side; the spines vary largely, some larvæ having all the spines black, some have the dorsal and ist lateral rows on $5^{\text {th, }} 7$ th, $9^{\text {th }}$ segments white, the rest black; some have white from 4 to I $\mathbf{I}$; some have white on 9 only; on 2 a collar of black simple spines; head broader than high, the top rather square, not much depressed, the processes larger, but similar to preceding stage, crowned with six points, one in middle, the rest about it surface glossy black, with many simple spines, of different sizes, usually all black, but some examples show a few white among the black; each with long hair. To next moult, in May 3 days, in August 2 days or somewhat less.

After $3^{\text {rd }}$ Moult.-Length $.3^{8}$ to .4 inch; color black, crossed on the posterior end of each segment with two or three lines or stripes of white, sometimes more or less macular; according to the breadth of these bands the larva is quite white or otherwise; the oblique marks on dorsum as before, more conspicuous; a yellow band runs along base in line with lower lateral spines, and the posterior part of each segment above this band shows an oblique bar, and some white spots and points; spiracles black in broad white rings; the spines long, and branching as before; the medio-dorsal row are always white; those of ist lateral row are usually white, but sometimes on 3 are black, or partly black; some examples have the and Jateral row wholly black, others white, or some of the last spines are parti-colored; on $z$ is a collar of simple white spines; head as before, the white spines predominating largely. To next moult in May 3 days, in August 2 days or somewhat less. 


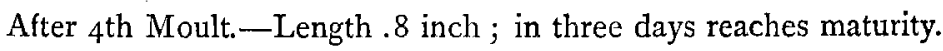

Mature Larva. - Length $\mathrm{x}$ inch; cylindrical, stout; armed with seven rows of long, tapering spines, one medio-dorsal, and three on either side; the dorsals beginning at 5 and ending at 12 , the upper laterals run from 3 to $\mathbf{I} 2$; the second laterals from 3 to 3 , but on 4 the spine is below the row, and in line with the spiracles; the lower laterals from 5 to I 2 ; from a little below the summit of each spine rise from three to five slender branches, about a central one which is a prolongation of the spine itself; the spines of the dorsal and upper lateral rows are largest and longest, and each has five branches, besides one or two lower down, of medium length, and some small spines, each branch and spine ending in a bristle; the spines of second lateral row are of medium length, with four branches; and those of the lower row are shortest and have three and four branches; in the green and white varieties of the larve all the spines are whitish or yellow, as well as the branches; in the black, the spines are yellow, mostly black-tipped, the branches as well, but the spines of the first lateral row are sometimes black to their bases; so those of second row are sometimes wholly, sometimes but partly black; 2 has a collar of six simple spines and two others are upon each side, in vertical line; the color of body varies much; some examples are cream-white, some greenish-white, with almost no markings, or the markings are obsolescent; others are velvetblack, the dorsum crossed by white stripes upon the posterior edges of the segments ; with two white divergent bars coming to an angle at the front of each dorsal spine, and running to the anterior edge of the segment; and with a similar oblique bar from each spine of the first lateral row on the lower side; along the base is a raised yellow stripe, and from this up to the second laterals the ground is crossed by abbreviated white stripes or patches, particularly on the last half of the segments ; above this the side is black; but individuals vary in the extent of this black area; sometimes the ground color is vinous-red; under side greenish, or honey-yellow, according to the color of upper side; the spiracles black in broad white rings; at the base of the second laterals from 9 to $I I$, or from 7 to $I I$, is usually a fulvous or orange patch, varying in extent; feet greenish or black; legs greenish or brown; head rather square, higher than broad, with high vertices; in the light examples the color of head is dull pink, in the dark ones it is black, shining, sometimes with a forked whitish stripe down the front; on each vertex a short, stout process, cylindrical, com. 
pressed in the middle, broad at the top, crowned by five equal, blunt-tipped spines around a sixth in the middle; each with hair; these processes are black in the black larvæ, and in the light ones either red or red with black tops; face and whole head thickly covered with simple white spines of variable length, all white, except that sometimes there are one or two of the longer ones on side face below the vertex which are black, or black and white; along back of head and down the sides is a row of these spines close set. From 4 th moult to pupation 5 days.

Chrysalis.--Length .8 to .9 inch; greatest breadth .24 to .26 inch; cylindrical; head case high, compressed transversely; at each vertex a long, conical process ; the mesonotum elevated, the carina very prominent, thin, nose-like, followed by a deep excavation; wing cases raised, flaring at base, compressed in middle, with a point on the margin; on the abdomen three rows of tubercles, those corresponding to the dorsal row of the larva small, to the first laterals large and conical, the pair in middle of the series particularly prominent, and those in the excavation silvered, gilded or bronzed, varying; color variable, many examples being dark brown, with lighter or with yellow-brown, and much reticulated with dark lines; others are dead-leaf brown; others are light, up to dead-white shaded slightly with yellow-brown, with a bronze lustre over the wing cases and anterior dorsal parts. Duration of this stage about 7 days.

Grapta Comma is found abundantly in New England and thence through the Northern States to Nebraska; also through Canada and in Nova Scotia; and to the South, at least as far as the Kanawha district of West Virginia. In the Northern States the species is two-brooded, in Kanawha three-brooded. It is seasonally dimorphic, the winter form being Harrisii (i. e., the form described by Dr. Harris), the summer form Dryas, Edw. Both these are figured in Butterflies of N. A., Vol. I. Where there are three broods, the middle one is made up of the two forms. Eggs laid by the hybernating females (form Harrisii) in April or May, give Dryas in May or June, and this is the first brood of the year. Eggs laid in July by Dryas give both forms in August-the second brood; and eggs laid in September by either form give Harrisiz in October. The first eggs are laid in April or May, according to the forwardness of the season. In 1882 , I obtained eggs from Harrisii, tied in bag over a hop spray, i 4 th April, and from 22 nd to 25 th May, had therefrom 35 Dryas, $17 \gamma, \mathbf{I} 8$ o. In 1874 , the first eggs were obtained roth May, and the result up to 27 th 
June, was 34 Dryas. In 1875 , the first eggs were 14 th May, and up to I 8 th June these gave I9 Dryas; no Harrisii in either case. In 1869 , on I 8 th June, one $\hat{f}$ Harrisii came from chrysalis, the only instance known to me in which that form has appeared in the first brood. So that in different years, at Coalburgh, there is a variation of at least a month in the laying of eggs by the hybernators, and consequently a month's difference in the appearance of the first brood. In Can. Ent., X., p. 69, I gave the results of rearing the several broods up to end of 1877 .

The larvæ, as described, are quite variable, when mature, the color of body being white, green or black; and the black examples vary much in the extent of the white or yellow markings. But neither color belongs especially to one form of the butterfly. Thus, of 50 larvæ, from eggs laid by Harrisii, in $\mathbf{1} 882$, but one was white, the rest being black. Of 34 larvæ from eggs of Harrisii, in 1874 , but 6 had black ground, and the rest were all light, several being cream-white. Of 23 larva from eggs of Harrisii, in 1875 , 1o were white or greenish, 13 more or less black. Of 60 larvæ from eggs of Dryas, I 873 , only one was white, the rest black. So that there is no apparent connection between the color of the caterpillar and the form of the butterily.

The caterpillars feed on Hop, Nettle, false Nettle, (Boehmeria cylindrica,) and Elm. I have found them at Coalburgh almost always on Hop and Boehmeria. The eggs are laid either singly or in small clusters upon the under side of the tenderer leaves, and the young larva eats a hole for itself in the substance of the leaf, and during the first stage feeds about this. For the first two stages it is exposed on the leaf just as the larva of G. Interrogationis is, but at the second moult behaves differently from that species, which makes no shelter for itself at any time. I watched three larvæ of Comma in Aug., r882, to learn exactly at what stage they began to protect themselves, placing them as soon as hatched upon a plant of Boehmeria set in flower-pot in my room. Very shortly after the second moult they had gotten to the bases of the third pair of leaves from top, two on one leaf, one on the other, and were engaged in drawing the edges of the leaves next base down with silk spun. To effect this they had bitten off the principal rib on either side the mid-rib, very near the edge of the leaf, and had cut quite to the edge. This leaf naturally curves the other way, so that the caterpillars were working at a disadvantage on the convex side. But notwithstanding this, they had, in course of an hour, 
bent down the edges and bound them together for one half inch. Next morning they all rested under their awnings, two under one, as at the first, and had fed off the tip end of the leaf. 'Twenty-four hours later the two larvæ had left what remained of their leaf, now scarcely longer than themselves, and each had betaken itself to another leaf. I had to transfer them to a larger plant, and next day found two under one leaf, again brought together as before. The other was upon the upper side of its leaf, and had closed that at the top. Still later this larva had drawn down the top of the plant and was concealed very nearly as much as the larva of Vanessa Atalanta is, which uses this same plant. Here it passed $4^{\text {th }}$ moult. So that these larvæ can adapt themselves to circumstances, and cover themselves on the upper as well as the lower side of the leaf, if expedient. I noticed that at the older stages the ribs were not bitten, nor were the edges of the leaf slit, the larva being able to draw down the edges without that aid. When lying under the shelter the larvae are at the inmost part, and are coiled up much like figure 6. In nature I do not remember to have found more than one caterpillar under one leaf.

The nearest ally of G. Comma is G. Satyrus Edw., a species common in the Pacific States to Rocky Mts., and taken even in Ontario. Mr. 'T. L. Mead captured two examples some years ago, north of London, Ont. Satyrus is dimorphic, its other form being Marsyas Edw., and the larvae remarkably resemble those of Comma in color and markings. So they - protect themselves in precisely same manner as do Comma larvae, and these are the only two American species of Grapta which have that habit, so far as known.

\section{DESCRIPTION OF A NEW SPECIES OF LYCAENA, FROM NEWFOUNDLAND.}

BY W. H. EDWARDS, COALBURGH, W. VA.

\section{LYCAENA ASTER.}

MaLE.-Expands I inch.

Upper side purplish-blue, the costal margin of primaries silvery; both hind margins narrowly edged black; secondaries have a marginal series of black points or minute spots; fringes white.

Under side white ; primaries have the hind margin edged by a fuscous line thickened at each nervule; a submarginal row of rounded black 